УДК 101.1:316.344.2:148.8

\title{
ВЛИЯНИЕ БЕДНОСТИ КАК СОЦИАЛЬНОГО ФЕНОМЕНА НА МИРОВОЗЗРЕНИЕ ЛЮДЕЙ В СОВРЕМЕННЫХ УСЛОВИЯХ ОБЩЕСТВЕННОГО РАЗВИТИЯ (СОЦИАЛЬНО-ФИЛОСОФСКИЙ АНАЛИЗ)
}

\author{
Зубкевич Лада Альбертовна, \\ lada-zubk@rambler.ru \\ Национальный исследовательский Нижегородский государственный университет \\ им. Н.И. Лобачевского, \\ Россия, 603950, г. Нижний Новгород, пр. Гагарина, 23.
}

Зубкевич Лада Альбертовна, кандидат философских наук, старший преподаватель кафедры философии Национального исследовательского Нижегородского государственного университета им. Н.И. Лобачевского.

Актуальность исследования определяется следующим: 1. Современный этап развития обществ в научной литературе характеризуется как переходный. Он отличается большим количеством социальных, политических, экономических и прочих изменений в жизни общества и отдельного человека. В результате этих изменений образуется множество факторов общественного развития, которые вступают между собой в противоречие. Все это влияет на мировоззрение людей, которое тоже изменяется. Изучение этих изменений важно для науки и общества. 2. Одним из таких факторов является бедность. Она в социологических и философских исследованиях признается препятствием для развития как отдельных обществ, так и человечества в целом. Более того, этот фактор считают источником многих глобальных проблем современности. Эти выводы мы встречаем во многих исследованиях, однако остаются слабо изученными особенности мировоззрения современных людей в состоянии бедности. Изучение этих особенностей актуально, т. к. бедные составляют большую часть населения Земли и влияют на происходящие изменения. Цель исследования - выявить влияние бедности как социального феномена обществ переходного периода на мировоззрение людей. Категории населения современных государств, которые по данным социологических оценок являются бедными, определяют область исследования. Методы. Посредством социально-философского анализа выясняется влияние свойств мировоззрения на развитие общества в условиях современного переходного состояния. Рассматриваются мировоззренческие особенности бе дных в аспекте отношения субъекта к объекту и особенности интерпретации собственного бедственного положения, характерные для бедных слоев общества. Проводится социальнофилософский анализ жизненных стратегий бедных. При осуществлении социально-философской рефлексии автор опирается на данные социологических исследований, принимая оценки ученых как доказанное. Также применяются метод сравнительного анализа авторских позиций социологов, «полидискурсивная» методология и методологический «принцип участного мышления». Результаты. Выявлено, что депривация является самым опасным субъект-объектным отношением и развивает альтернативные средства адаптации к действительности. Бедные без помощи общества не могут вырваться из нищеты, поскольку данное состояние не является стимулятором выработки новых продуктивных стратегий деятельности.

Ключевые слова: Депривация, андеркласс, культура бедности, эффективные жизненные стратегии, благосостояние, социальное неравенство, социально-экономическая зависимость, зависимые установки. 


\section{Введение}

Современный этап развития обществ в современной научной литературе характеризуется как переходный. Он отличается большим количеством социальных, политических, экономических и прочих изменений в жизни общества и отдельного человека. В результате этих изменений образуется множество факторов общественного развития, которые вступают между собой в отношения противоречия. Одним из таких факторов является бедность. Она в социологических и философских исследованиях признается препятствием для развития как отдельных обществ, так и человечества в целом. Более того, это фактор считают источником многих глобальных проблем современности. Следовательно, изучение особенностей мировоззрения современных людей в состоянии бедности представляется актуальным. Категории населения современных государств, которые по данным социологических оценок являются бедными, определяют область исследования.

Автор основывается на определении бедности как состояния жизни человека, чей уровень материального обеспечения соответствует черте бедности или ниже ее, где последняя объективно определяется средствами методик измерения бедности. Бедность как социальный феномен измеряется, а также имеет бинарные оппозиции: депривацию (исключение из общества) и социальное неравенство (влияние материального положения на положение человека в обществе). Более подробное раскрытие понятия бедности находится за рамками данной статьи [1]. Также в данной статье понятие «мировоззрение» используется в широком смысле как субъект-объектные отношения человека и мира. Мировоззрение понимается нами как система взглядов на мир в целом и на отношение человека к этому миру, включая совокупность принципов, ценностей, идеалов и убеждений, определяющих отношение человека к действительности и формирующих стратегии поведения людей в системе социальных связей. Субъектом системы мировоззрения (носителем мировоззренческого поля) могут быть отдельный человек, социальная группа, общество в целом [2].

Предметом данного исследования является влияние бедности как социального феномена обществ переходного периода на мировоззрение людей, объектом - бедность как феномен общественного развития. В связи с этим цель данной статьи - определить изменения в мировоззрении человека под влиянием бедности, учитывая переходное состояние современных обществ, а также выяснить, какие измененные свойства мировоззрения (как общественного, так и лично бедного человека) представляют наибольшее препятствие для развития человечества, и таким образом понять возможность влияния на систему мировоззрения для преодоления бедности как фактора развития.

Для достижения указанной цели в исследовании ставится ряд задач: выявить отличительные черты мировоззрения бедных в аспекте отношения субъекта к объекту (бедного человека к окружающему миру), специфику интерпретации собственного бедственного положения, характерную для бедных слоев общества; провести социальнофилософский анализ жизненных стратегий людей, попавших в ситуацию бедности, выделив в них факторы, представляющие угрозу для общественного развития; установить зависимость стратегий от мировоззрения человека.

При осуществлении социально-философской рефлексии автор опирается на данные социологических исследований, принимая как доказанное их оценки, анализ данных, используемые критерии стратификации общества. Однако, учитывая определенную разницу в авторских позициях социологических исследований, с целью максимального рассмотрения факторов их исследования, которые влияют на результат, применяется метод сравнительного анализа авторских позиций социологов. Полученные 
результаты являются теоретической базой для выполнения задач исследования, в котором исследуется «полидискурсивная», «полипарадигмальная» методология, эклектически сочетая вышеуказанные концепции, абстрагируясь от межпарадигмальных противоречий. Сочетание отдельных компонентов этих концепций осуществляется без потери идентичности и без изменения их категориальных структур. Используется «принцип участного мышления» [3, с. 4], где разрозненные элементы группируются в едином герменевтическом поле.

\section{Влияние бедности как социального феномена общества переходного периода на оценку бедным человеком окружающей его социальной реальности}

При анализе социологических концепций выявлено, что одни социологи выделяют универсальность отношения бедных к миру (например, «культура бедности»), другие подчеркивают его специфичность, зависящую от обстоятельств, при которых человек попал в ситуацию бедности. Сторонники универсализма так представляют отношение бедных к миру и их психологический портрет: агрессивность, зависть, грубость, ненависть к культуре, склонность к пьянству, безделью, правовой нигилизм, ничем не мотивированная самоуверенность, следствием которой становятся разного рода ксенофобии, в том числе расизм, антисемитизм, вандализм и пр. Бедные не берут на себя никаких обязательств, в основном рассчитывают на безвозмездную помощь других членов общества $[4$, с. 143-144, 149]. Основным атрибутом бедности являются «зависимые установки» в мировоззрении - «ориентация социальных акторов на отношение социально-экономической зависимости». Социально-экономическая зависимость является состоянием и феноменом сознания [5, с. 59-62]. Под зависимыми установками понимается стремление пользоваться посторонней помощью, как моральной, так и материальной. Это предполагает делегирование ответственности за свое жизнеобеспечение и готовность отказаться от ряда своих прав и свобод в обмен на материальную обеспеченность [6, с. 2]. О. Льюис в институте бедной семьи отмечает незащищенное детство, соперничество за ресурсы внутри семьи, низкую привязанность членов семьи друг к другу, но в индивидуальной психологии - чувство маргинальности, зависимости, неполноценности, отсутствие волевого контроля, фатализма [7]. Согласно О. Льюису, бедность - это субкультура, ценности, нормы и правила которой отличаются от культуры данного общества. Это хроническое состояние, передающееся через поколения, поэтому люди лишены шансов справиться с бедностью. Субкультура бедности - продукт ситуации отчаяния и безнадежности. Депривация порождает фатализм и безысходность. О. Льюис проводил исследования в Мексике и на Кубе, в результате проведенного сравнения сделал вывод, что культурные и материальные показатели не всегда совпадают. В отличие от Мексики, культуры бедности на Кубе не существует, хотя материальные условия жизни схожи. Напротив, после революции 1961 г. в этой стране наблюдался подъем патриотизма, веры в будущее, социальной активности [8]. Таким образом, культура бедности формируется в ситуации депривации. Бедность делает жизнь людей не сопоставимой с жизнью других, приспособление к ее условиям происходит с помощью особой адаптации, что изолирует их от общества и замыкает в себе. В результате особой адаптации формируется система ориентиров и позиций, образующих культуру бедности [9].

Некоторые авторы выделяют обуславливающие специфичность внешние обстоятельства и используют термин «андеркласс», противопоставляя его классу работающих. «Общественный андеркласс по своим размерам и форме является относительно новым явлением» $[9$, с. 46]. В состоянии бедности у людей снижаются социальные по- 
требности, претензии и активность. Механизм такого регресса работает по следующему принципу: при снижении уровня жизни из мировоззрения «вымываются сложные социокультурные потребности», работает установка на ежедневное выживание, а не на преодоление бедности. Мировоззренческая установка на выживание изменяет хозяйственную практику через сознание и поведение людей, делая ее неэффективной [10, c. 73-74].

Нехватка материальных ресурсов серьезно ограничивает жизненный выбор. Нет культурных различий между бедными и не бедными, но есть рациональная адаптация к разным условиям неопределенной и неустойчивой внешней среды. Бедность - это состояние, которое может влиять на психику человека, понижать его когнитивные функции. Бедные сосредоточены на решении текущих бытовых проблем, и у них не остается когнитивных ресурсов на решение более сложных задач. Поэтому они хуже учатся, работают, плохо решают тесты и т. п. Такая ситуация создает условия консервации состояния бедности. Однако бедность - это временное состояние ограничений в жизни, к которому человек адаптируется с помощью тех или иных психологических особенностей своей личности [8], ему в этом помогают те или иные мировоззренческие особенности [15].

Другие авторы рассматривают индивидуальные качества бедняков как самостоятельный (и главный) фактор их пребывания на социальном дне [10]. Так, представители социально-когнитивной теории социального класса считают, что субъективный социально-экономический статус лежит в основе индивидуальных психологических характеристик. Данный подход акцентирует внимание на субъективном восприятии человеком себя как бедного (на уровне мировоззрения), а также на сочетании этого восприятия с материальными условиями бедности, которые объективно влияют на социальнопсихологические характеристики индивидов. В результате постоянного сопоставления себя с другими у людей на уровне мировоззрения формируется собственный образ (или идентичность). «Данные представления являются мощным регулятором жизнедеятельности, оказывают влияние на различные социально-психологические показатели личности, поскольку представляют собой часть Я-концепции личности» [18, с. 97].

Проиллюстрировать влияние бедности на мировоззрение человека можно исследованием Е.С. Балабановой, цель которого - проанализировать самопозиционирование в социальном пространстве разных категорий бедного населения. На основе социологических данных, учитывающих варианты оценки социальной реальности гражданами РФ, были выделены условные группы респондентов. 71 \% условной группы «исключенных» составляют вынужденные мигранты, их бедственное положение характеризуется такими «объективными» факторами, как отсутствие здоровья, связей в социуме, низким доходом и плохой имущественной обеспеченностью. Людей больше всего огорчает отсутствие родных и близких рядом, нехватка общения, плохое отношение к ним и их семьям со стороны окружающих. Однако если семьи рядом, то они являются не столько фактором помощи, сколько источником трудностей. В исследовании делается вывод, что люди в подобном положении не в состоянии выгодно «подать себя», творчески подойти к решению проблем. Они обречены на пассивные формы совладания с материальными трудностями. Таким образом, «неэффективные формы поведения» запрограммированы в самой бедности [5]. Условная группа «традиционалистов» также плохо адаптирована к современной действительности, т. к. ориентирована на константы прошлой жизни в Советском Союзе: стабильность жизни, материальное обеспечение, личную защищенность, коллектив, условия труда, соответствие специальности. Поэтому сейчас они больше заботятся о своем здоровье, приспосабливаются 
к обстоятельствам и людям, экономят, более рационально ведут бюджет, стараются не обращать внимания на трудности, уделяют больше времени и сил своей семье. В исследовании делается вывод, что подобные ориентации не способствуют повышению доходов и не смягчают психологические последствия бедности [5]. Однако среди бедных есть адаптированные группы. В условной группе «независимых» люди чувствуют себя способными повлиять на происходящие с ними события и полагаются на собственные силы [5].

Другим примером могут служить данные социологических исследований политического поведения 1992-1996 гг. и 1996-2000 гг. Было установлено, что малоимущее население (сельские жители, пенсионеры, лица со средним образованием) имеют пассивную, негативную позицию в своих оценках окружающей действительности. Неимущие граждане имеют активную, последовательно негативную позицию по вопросам общественной жизнедеятельности, отмечают нарастание негативных тенденций в экономике, разочарование в действиях всех уровней власти. Также в исследованиях констатируется, что после дефолта 1998 г. в РФ произошло резкое ухудшение материального положения, поэтому негативное отношение усилилось. Появилась угроза социального взрыва [11].

С точки зрения Сорокиной А.В. мировоззрению бедных присущи симпатии к левым партиям и их представителям, однако «бедные вряд ли станут ядром социального протеста»; потребность в государственной опеке наряду с «низким уровнем оценки собственных возможностей и невысокой активности в трудовой сфере». Самые бедные слои много говорят, что должны делать другие, но ничего не делают сами, они легко подкупаются разными политическими силами. Политические установки малоимущих более радикальны. Социальная терпимость неимущих связана с боязнью любых серьезных преобразований, поскольку «все они могут поставить под угрозу физическое выживание данного слоя» [11, с. 16].

Таким образом, в разных исследованиях мы видим противоречивые фактические данные по позициям неимущих и малоимущих групп, также исследователи не видят причинно-следственной связи между историческими и социологическими фактами. Так выводы об инертности, иждивенчестве бедных слоев населения, о характерной для неимущих патерналистской модели социального поведения непоследовательны [12]. Объективно в социологических исследованиях существуют противоречия между социологическими, историческими фактами и их интерпретациями исследователями, что отражает противоречивость самого процесса развития на современном этапе, а также противоречия в мировоззренческих основаниях исследователей и их респондентов, это создает нежелательные когнитивные последствия в изучении процессов общественного развития. Причиной расхождения социологических данных в отечественных исследованиях может быть неоформленность интересов респондентов, характерная для молодого класса российских бедных, их разрозненность, противоречивость отношения «проигравших» к происходящему в общественной жизни. Классовый интерес у неимущих не осознан, они озабочены своим физическим выживанием, но имеют мировоззренческие установки, схемы деятельности советского человека, и в этом обнаруживается противоречие, влияющее на интерпретации. Например, интерпретации патернализма. Если мы понимаем государство как противопоставленное человеку, возвышенное над ним и антагонистичное ему образование, то подобные факты могут быть расценены именно как иждивенчество (это свойственно современному капиталистическому мировоззрению). Если государство понимать как совокупность делегированных для осуществления управленческих функций членов общества, равных всем остальным, 
обладающих не властью над обществом, а обязанностями по отношению к нему, то описанное выше отношение ныне «проигравших», бывших советских людей, является принципиальной, деятельной позицией участия в управлении обществом (что свойственно мировоззрению советских лет).

В науке история интерпретаций по рассматриваемому вопросу складывалась следующим образом. Первоначально О. Льюис выделил субкультуру бедности как отдельную систему ценностей, имеющую в качестве характеристик дезорганизацию, патологию, низкий уровень участия в социальных институтах. Далее субкультура бедности понимается как результат вынужденного ситуационного поведения. Проявление этой субкультуры касается отдельных аспектов жизни, но в целом она не выделяется из общества. Далее модель понимания меняется, субкультура бедности рассматривается как положительная адаптация к условиям, в которых вынуждены существовать бедные. Источник патологии - процессы в общественной системе, которые лишают бедных ресурсов. Ответственность несут не только бедные, но и общество в целом. Модель адаптационного поведения бедных вписывается в общую систему ценностей, не приводя к формированию контркультуры.

Исследователем создается определенная модель-метафора, которая фиксирует фрагмент реальности, осознанно учитывая его многомерность и «противоречивость душевного мира познающего субъекта» [13, с. 62-63]. Никакое исследование немыслимо без познающего субъекта. Для научного моделирования важна интерпретация. Через нее устанавливаются практики преобразования мира и самой личности. Интерпретация формирует новые смыслы бытия. Но поскольку речь идет о позиции личности исследователя, то неизбежны противоречия и столкновения толкований. Поэтому необходимо учитывать, что любые интерпретации основаны на мировоззрении исследователя, которое может быть иным, чем мировоззрение объекта исследования, в этом особенность изучения любых социальных вопросов. Если данное обстоятельство не учитывается при исследовании, то созданная модель-метафора перестает быть адекватной объекту и научная беспристрастность исследователя становится сомнительной.

Однако несмотря на отмеченное выше многообразие интерпретаций, в результате их анализа при применении полипарадигмальной методологии может быть сформировано единое герменевтическое поле, где отличительные черты мировоззрения бедных предстают следующим образом. Социально-экономическая зависимость является состоянием и феноменом сознания бедного человека. Однако в ситуации депривации формируются и иные особенности мировоззрения. Бедность делает жизнь людей не сопоставимой с жизнью других, приспособление к ее условиям происходит с помощью особой адаптации, что изолирует их от общества и замыкает в себе. В результате особой адаптации формируется особая система ориентиров и позиций [14].

Индивид ведет себя в разных жизненных ситуациях так, как он оценивает себя и свое место в окружающей среде. Представители низшего социального класса в меньшей степени могут контролировать свою жизнь, больше подвержены внешней угрозе, зависимы от других людей, склонны к эмпатии и состраданию, доверчивы и благородны, больше готовы жертвовать для других. Существование в рамках данного социального класса - это нахождение в рамках изолированного социального контекста, где есть объективный опыт, недостаток материальных ресурсов и заниженное субъективное восприятие себя в сравнении с представителями других социальных групп, есть особенности мировоззрения, где связь между объективным статусом (уровень дохода) и субъективным самовосприятием может быть мала. «Непосредственно осуществляемые действия», планирование, «представление о должном, то есть система общих 
взглядов на жизнь и ценностных ориентаций» [5, с. 60], которые составляют отношение человека к действительности, в ситуации депривации деформированы. Недепривированные бедные не испытывают необходимость в особой адаптации, и поэтому не имеют указанных особенностей мировоззрения, не изолированы от общества особым социальным контекстом.

Особенным представляется мировоззрение граждан бывших социалистических стран. Социалистическое прошлое обусловило специфику отношения к окружающему миру людей, оказавшихся бедными. Общество, ранее не знающее социального неравенства, дихотомически разделилось на «победивших» и «проигравших» в ходе реформ. Для «проигравших» характерны ценности безопасности, равенства, справедливости, стабильности и защищенности, а также ожидание помощи. У таких людей развивается зависимость как мировоззренческая установка. Это проявляется в восприятии себя как пассивного объекта действия других людей, в «представлении о том, что государство обязано гарантировать гражданам приемлемый уровень жизни, заботиться о них», в «установке на традиционализм, недостижительские ценности» [5, с. 61-62]. «Победившие» успешно адаптируются, принимают капиталистическую культуру, идеи индивидуальной свободы, прагматизма, эффективности, успешной карьеры и подъема уровня жизни. В деятельности они используют инновационные экономические стратегии [5].

Специфика отношения российских бедных к действительности в том, что это бедность грамотного, трудоспособного населения и социабельных людей, живущих до начала девяностых годов в условиях относительного достатка. Такое отношение бедных эмоционально насыщено, потенциально социально-политически нестабильно и обусловлено неблагоприятным социально-психологическим самочувствием, вымиранием целых городов и закрытием отраслей производства [11]. Последнее, впрочем, наблюдается и на Западе (например, г. Детройт, штат Мичиган, США).

Таким образом, ситуация бедности изменяет отношение человека к миру. Положение зависимости рождает потребность в посторонней помощи, депривация является источником антагонизма между бедными и не бедными, отсюда агрессивность и прочие негативные проявления, присутствующие в отношении бедных к окружающему миру. Бедные, особенно депривированные, не берут на себя обязательств по отношению к обществу, т. к. не имеют объективных возможностей их выполнить, развивают при этом другие средства адаптации. Причиной такого отношения является не столько низкое материальное положение, сколько осознание себя исключенным из общества. И наоборот, осознание себя деятельной частью общества делает бедных наиболее социально активной его частью. Такое осознание зависит от внешних обстоятельств, которые привели к бедности и сопутствуют ей.

\section{Влияние бедности как социального феномена общества переходного периода на самооценку человека}

Выделим три вопроса в аспекте субъективного восприятия бедности. Первый специфика самосознания бедных в современной России. Второй - «феномен ухода в себя» в ситуации бедности. Третий - мировоззренческие установки (бедность как норма или бедность как бедствие) и их значение.

В Аналитическом докладе от 2013 г. Института социологии РАН констатируются следующие факты: в нашей стране происходит ухудшение отношения к бедным, в то же время бедность растет и распространяется среди работающих; реальный уровень жизни снизился, но бедные стали иметь больше домашнего имущества; увеличивается число бедных более 5 лет (консервация бедности) и массово появляются новые бедные 
[16]. Совокупность этих фактов парадоксальна с точки зрения доклада. Подобные парадоксы являются причиной роста социальной напряженности. Однако, с нашей точки зрения, парадокса здесь нет. В данных фактах проявилась специфика современной бедности в России. Она обусловлена предыдущим развитием страны и противоречивостью сегодняшнего переходного процесса. В обыденное сознание бывших советских граждан насаждается протестантская аксиологическая норма - бедным быть грешно, что противоречит нашим традиционным установкам. Однако в современных условиях переходных процессов в обществе наличие занятости и доходов сегодня не является гарантией стабильности завтра. Наличие работы не спасает от бедности. Данные изменения в оценочной части мировоззрения наряду с отсутствием уверенности в завтрашнем дне вносят диссонанс и ощущение катастрофизма в самооценку любых людей (как говорят, от сумы и от тюрьмы не зарекайся). Поэтому срабатывают испокон веков существовавшая поведенческая установка - накапливать на черный день и самый популярный способ инвестирования в будущее - покупать и хранить домашнее имущество.

Объективное положение людей в общественной иерархии не соответствует их субъективным представлениям в силу чрезвычайно резкой динамики социальных изменений российского общества, быстротечности жизненных реалий, следствием этого становится потеря статусной идентичности бедного человека. По данным социологических опросов (1998-2002 гг., РФ) россиян считают себя бедными по уровню жизни, но относят себя к среднему слою по оценке социального статуса [17]. В чем причина? Возможно, существует разное понимание среднего слоя. В обыденном понимании это ориентация на образ жизни большинства (как все, не хуже всех), в социологических измерениях подразумевается среднее значение дохода всего населения. Затруднена объективная оценка статуса человека тем, что общественное сознание и наука еще не выработали удовлетворительных критериев имущественного расслоения для российского общества, а западные исследования постиндустриальности для нас не применимы, т. к. в России аксиологические акценты в мировоззрении смещены на эмоциональные, духовные аспекты самоидентификации индивида в общественной иерархии [18]. Поэтому субъективные составляющие стратификации становятся «одним из немногих опознавательных знаков, служащих ориентиром индивида в социальном пространстве» [19, с. 3-12], одним из которых выделяют «микроуровневую идентичность» (ориентация на оценки ближайшего окружения).

Такая ориентация на уровне личности создает впечатление стабильности, но при этом усиливается отчуждение личности от государственных институтов, происходит «уход в себя», сопровождающийся нежеланием «принимать решения и нести за них ответственность» [20, с. 15-16]. «Феномен ухода в себя» среди бедных, сопровождающейся социальной изоляцией, был отмечен в Англии в 1930 г. Это послужило поводом для начала исследований и создания теории социального исключения. В России «уход в себя» не приводит к изоляции, но приходится говорить о спаде социального участия. По данным социологов при переживании данной ситуации наблюдается нервное напряжение, физическое и психическое истощение у половины респондентов, у 62 \% произошло ухудшение здоровья из-за трудной жизненной ситуации, почти у всех уменьшается вера в себя и свои возможности, увеличивается чувство зависимости от внешних обстоятельств [5]. Другими словами, ситуация стресса в условиях бедности приводит к тому, что психологически люди слабеют, чаще «ломаются», что выражается в общем снижении самооценки и веры в свои силы. Но с повышением дохода, имущественной обеспеченности, поддержки социального окружения повышается и самооценка людей, они начинают относить себя к более высокому социальному слою [5]. Через 
создание внутреннего мира личности и возможности «уйти» туда при тяжелых личностно-эмоциональных моментах, микроуровневая идентичность создает «форпост» для «возможности обратного воздействия на общество в целом». Так при переходных общественных состояниях происходит формирование новых ценностных и мировоззренческих установок, норм и правил, а также корректировка или отрицание старых, что влияет на понимание человеком своего места в социальной структуре.

Указанная выше особенность мировоззрения бывших советских людей приводит к следующему противоречию самооценки современных российских бедных. Социологические исследования показывают, что бедное население в своем низком уровне жизни винит социальную защиту, углубление социального неравенства, социальную дезадаптацию и отсутствие восходящей социальной мобильности. В то же время источниками улучшения своего положения считают государство и субъекты, обладающие материальными ресурсами, в социально-экономической зависимости от которых они состоят [11]. Данное противоречие возможно объяснить возникшими в переходных процессах особенностями мировоззрения российского общества.

В современной России, в отличие от СССР, люди не ощущают себя хозяевами жизни, но эта советская мировоззренческая установка еще не забыта, существование этих двух установок в одном мировоззренческом поле (у одного субъекта) способствует социальной напряженности. Дело не в том, что еще живы и дееспособны «рожденные в СССР», а в представлениях о жизни, которые передаются из поколения в поколение. Они хранят еще патриархальные установки Российской империи о «царебатюшке» и добром барине, заступниках и радетелях. Именно это советская идеология и коммунистическая мораль пыталась изжить, именуя мелкособственническими настроениями. События разрушения Советского Союза добавили новые черты в самовосприятие бедными своего положения: «раздраженно-оценочное восприятие» богатого сословия, поиск виноватых, требования создания эффективной системы перераспределения материальных благ. «Негативная социализация подрастающего поколения» (неблагополучие), «негативная ресоциализация взрослых» считаются следствием искусственно созданной в процессе реформ бедности. Свойственно ощущение фрустрации, вызванное высокими ценами, низкими доходами, ежедневной заботой о завтрашнем дне. Нет адекватного восприятия собственной бедности. Настроения варьируются от обреченности до ярости, особое раздражение вызывает не бедность сама по себе, а осознание представителями бедных слоев вопиющего социального неравенства. Знание о природе происхождения крупных состояний приводит к оценке всех людей богатого сословия как «людей без чести и совести», происходит отторжение и дискредитация идеи материального успеха. Одновременно присутствует самокритика и попытки поиска внутренних причин социальных неудач. Признается личная ответственность человека за результаты жизни [11].

Аксиологической особенностью мировоззрения становится то, как бедный человек осознает свой статус, воспринимает состояние бедности как бедственное положение или как норму жизни. Эта оценка влияет на поведение человека, его стратегии деятельности. Восприятие бедственного положения как нормы приводит к социальному иждивенчеству. Так, в США многие предпочитают жить на социальные пособия и не собираются работать. Отсутствие работы может оказаться следствием рационального выбора [9].

Отсутствие денег и работы самих по себе не является достаточным для оценки человеком своего положения как бедствия. Человек ощущает себя бедным из-за «щемящего чувства тревоги о том, что случись какая-то беда, не хватит средств, и тогда вы и вся 
ваша семья пропадете». В жизни человека важно субъективное ощущение счастья. Но это чувство не всегда соответствует уровню благосостояния. «Порой люди приспосабливаются к, казалось бы, невыносимым условиям. Они могут получать свою толику счастья и быть вполне довольными жизнью в местах, где властвует смерть и нищета» [21, с. 15]. Здесь мы также сталкиваемся с противоречиями интерпретаций. «Случается, что живущие в тяжелейших условиях бедняки уверяют, что живут хорошо, а богачи, имеющие, казалось бы, все, крайне недовольны своей жизнью» [21, с. 45]. Однако объективное положение богатства и бедности демонстрирует неадекватность таких самооценок действительности. На это указывают результаты опросов населения разных стран об оценке качества своей жизни [21]. Ощущение счастья не наделяет благосостоянием бедного и не лишает богатства богатого. Но ощущение счастья, чувство удовлетворенности жизнью влияют на деятельность человека и, как следствие, на бедность [21].

В результате проведенного анализа мы пришли к следующим выводам. В современной России обнаружена специфика самовосприятия бедными своего положения. Она обусловлена предыдущим развитием и противоречивостью сегодняшнего переходного процесса. На самооценку бывших советских людей и их потомков, попавших в ситуацию бедности, влияет насаждение чужих культурных норм в ее понимании. Это приводит к появлению особенностей в оценочной части мировоззрения отдельного человека и общества в целом. Происходит потеря статусной идентичности обедневших российских граждан. Причиной этого является несоответствие самооценок людей объективному их положению в социальной иерархии. В самоидентификации присутствует ориентация на свои оценки, оценки ближайшего окружения, в результате этого создается впечатление стабильности, наблюдается «феномен ухода в себя», посредством него в человеке создается мировоззренческий «форпост» для обратного воздействия на общество. Данное воздействие при переходных общественных состояниях приводит к формированию новых ценностных и мировоззренческих установок, норм и правил, а также к корректировке или отрицанию старых, что влияет на понимание места человека в социальной структуре.

Восприятие бедным человеком своего положения как нормы приводит к обременительному для общества социальному иждивенчеству. Когда бедность воспринимается как бедствие, возникает потребность избавиться от бедствия, но отсутствие в обществе объективных для этого возможностей приводит к ощущению личной катастрофы, к разным вариантам адаптации и даже к приспособлению к самым невыносимым условиям жизни.

Интерпретация бедными собственного положения зависит от социальноэкономических, политических условий общества и господствующих в нем культурных и мировоззренческих установок. Самоидентификация зависит от психоэмоционального и физического состояния индивида. Противоречия между самооценкой человека в состоянии бедности и окружающей его реальностью могут привести к социальному взрыву. Кроме социального протеста существуют другие варианты избавления от ощущения катастрофы. Это может быть «уход в себя», создание альтернативного мира или внутреннее приспособление и адаптация, которые даже могут создать иллюзию счастья. Таким образом, на основании исследования самооценки бедных, их интерпретаций своего положения можно сделать следующий вывод. Бедные, оставленные один на один со своей нищетой, никогда не вырвутся из этого положения, т. к. наталкиваются на множество не столько внешних, сколько внутренних преград. В сочетании с неблагоприятной социально-экономической и политической ситуацией бедность «консервируется», на уровне мировоззрения приобретает характер субъективной жизненной нормы. 


\section{Жизненные стратегии бедных как результат отношений «мир-человек»}

В данном параграфе проводится социально-философский анализ социологических исследований жизненных стратегий людей, попавших в ситуацию бедности. Жизненные стратегии являются частью мировоззренческого поля любого субъекта мировоззрения. Согласно данному во введении определению мировоззрения, компонентом последнего являются программы деятельности людей, которые по сути основываются на жизненных стратегиях. Поэтому важно изучить связь этих стратегий и мировоззрения.

В социологических исследованиях существует разнообразие авторских интерпретаций жизненных стратегий людей в состоянии бедности. Интерпретации зависят от отношения исследователей к бедности как феномену. Среди них можно выделить позиции, считающие данные стратегии субъективно обусловленными, неэффективными (мировоззренческая установка: бедные сами виноваты в своей бедности). Также есть мнения, что эти стратегии объективно обусловлены, но неэффективны (мировоззренческая установка: причина бедности - не зависящие от людей условия), и противоположный взгляд - стратегии бедных могут быть эффективными.

Если обобщить описание субъективно обусловленных, неэффективных стратегий, то картина представляется следующей. Нормой поведения в рамках таких стратегий является деятельность, направленная на выживание, а не на развитие и накопление. Бедные люди не понимают связи «между экономическими затратами и их результатами», поэтому не хотят инвестировать в физический или человеческий капитал, приспосабливаются к неудовлетворительным условиям, не пытаясь их изменить, отрицательно относятся к богатым [22, с. 70].

Примером такой интерпретации может служить исследование российской бедности Е.С. Балабановой, в котором обосновывается существование у бедных разных субъективно обусловленных жизненных стратегий. Выделено несколько групп респондентов на основании наличия или отсутствия аксиологических установок на социальноэкономическую зависимость. Указывается зависимость этих установок от мировоззрения опрошенных, а не от уровня их обеспеченности. Упомянутый в первом параграфе кластер «традиционалистов» осуществляет «бегство от рынка», вместо «живых денег», использует «подпорки бесплатности», ищет внешние источники поддержки своего жизнеобеспечения - так «идет приспособление не к рыночным преобразованиям, а к кризисным условиям существования». Другая группа живет за счет социальной поддержки, которая понимается не только как моральная поддержка и советы, но и как материальная помощь (в том числе вещи, продукты от родных). Здесь социальный ресурс компенсирует недостаточность личных возможностей: «здоровья, самоэффективности, психологической устойчивости и способности зарабатывать». Таким образом, являясь «бедными», из-за использования своих средовых ресурсов они не оказались «исключенными» [5, с. 73-74]. Кластер «плывущих по течению» состоит из здоровых, психически устойчивых людей, им «денег хватает на текущие расходы», они не замечают своих проблем, дистанцируются от них, живут «как придется», имеют низкую трудовую активность, не обдумывают свои действия и поступки, наименее критично относятся к себе. Стратегия кластера «независимых» сочетает «успешность», «самоэффективность» и независимость. Живут в основном на зарплату (социальных выплат минимум), в трудной жизненной ситуации ищут заработок, приобретают новые профессии, открывают свое дело, не нуждаются в родственной поддержке.

В результате исследования обнаружено пять жизненных стратегий: 1) неспособность обеспечить себя своими собственными силами; 2) экономическая пассивность; 3) «активное использование внешних источников поддержки», делегирование ответст- 
венности в решении проблем; 4) «дистанцирование от проблем и движение по течению», «свобода как воля»; 5) «мобилизация индивидуальных ресурсов», «интенсификация оплачиваемой занятости». Первые три стратегии базируются на мировоззренческих установках зависимости, последние две - это независимые стратегии [5, с. 75-77]. Все они могут быть результативными в конкретный момент, т. е. могут обеспечить физическое выживание, но избавление от бедности приносит только пятая стратегия.

Примером интерпретации бедности как результата неэффективных, объективно обусловленных стратегий служит исследование американского социального психолога Грискевициуса и его коллег. Они считают, что неэффективные стратегии объективно обусловлены статусом человека в детстве. Выделяют два типа стратегий распределения ресурсов: медленные и быстрые. Быстрые стратегии - стремление извлечь немедленную выгоду, не заботясь о долговременных последствиях, что приводит к бедности. Медленные стратегии приводят к богатству, т. к. ориентированы на долгосрочное планирование. Чем выше уровень недостатка ресурсов в детстве, тем более вероятен выбор быстрых стратегий. Выросшие в богатых семьях менее склонны к риску и импульсивному поведению, чем выросшие в бедных семьях. Последние ориентированы на то, чтобы сразу потратить имеющиеся деньги и улучшить текущую жизненную ситуацию, а не откладывать на будущее [23].

Исследователи считающие, что стратегии бедных могут быть эффективными, источником эффективности рассматривают саму бедность как «катализатор человеческой деятельности». Бедность активизирует человека, мобилизует его способности. Поэтому считается, что социальные пособия снижают мотивацию к деятельности [24]. Бедные несут ответственность за каждый шаг и в своей жизни, т. к. могут рассчитывать только на самих себя. Это обеспечивает огромный жизненный потенциал бедных, в отличие от богатых, которым достаток дает возможность не заботиться о составляющих своей жизни [25]. Именно использование традиционных связей и отношений, подкрепляемое надеждой на патернализм государства, является той стратегией, которая поможет преодолеть бедность, т. к. рыночные стратегии адаптации бедным не доступны [17].

На жизнь бедных влияет множество факторов: отсутствие у людей возможности выбирать способы деятельности; внутренние проблемы людей, порожденные бедностью, которые не дают человеку реализовать эти возможности, даже если они появляются. Эти факторы в совокупности становятся «ловушкой нищеты» [26, с. 13], которая воспроизводится в следующих поколениях. Абхиджит Банержи утверждает, что «большинство бедных людей, если бы у них появилась малейшая возможность, сумели бы вырваться из бедности» [27]. Обвинения бедных в располагающем к бедности характере («они ленивы, недисциплинированные или недостаточно трудолюбивые») являются голословными [27]. Бедные не могут выбирать способы деятельности из-за отсутствия ресурсов для инвестиций и возможности получить образование, устраиваться на работу. Из-за внутренних проблем бедные принимают нерациональные решения, не пользуются возможностями небольших, но доходных инвестиций, сберегают слишком мало и занимают слишком много.

Жизненные стратегии не эффективны, если имеют временный и в основном индивидуальный результат. Эффективность жизненных стратегий необходимо оценивать с точки зрения роста благосостояния всего общества, при этом рассмотрении она не зависит от уровня дохода. «Под благосостоянием понимается материальное благосостояние, включающее доход и имущественное положение; физическое и психическое благополучие, выраженное в состоянии здоровья и счастья; образование и возможность принимать участие в жизни гражданского общества в условиях демократии и верховен- 
ства закона» [21, с. 41]. Неэффективным может быть и поведение богатых людей. Это наблюдается, когда разбогатевшие люди, получая политические преимущества, ослабляют систему государственного здравоохранения и образования, препятствуют внедрению новых изобретений и новых способов ведения дел. Только прогрессивное развитие общества может увеличить благосостояние людей. Прогресс сопровождается «созидательным разрушением». «Новые методы сметают старые, разрушая жизнь и лишая средств к существованию тех, кто зависит от старого порядка», если они обладают политическим влиянием, то могу «объявить новые идеи вне закона или затормозить их внедрение» [21, с. 24-27]. Именно факт существования бедности и страданий заставляет обращаться к поиску новых способов преодоления «разрыва» между бедностью и богатством, путей ликвидации социального неравенства [21, с. 26-27]. Таким образом, эффективной может считаться только деятельность, которая способствует прогрессивному развитию общества, направленная на преодоление социальной несправедливости и социального неравенства. Справедливость заключается в пропорциональности доходов и индивидуального вклада в развитие [21].

В результате проведенного в данном параграфе анализа было выявлено следующее. Несмотря на разницу в исследовательских интерпретациях, обнаружены одни и те же характеристики жизненных стратегий бедных. Деятельность бедных направлена на выживание. Бедные не накапливают сбережения, не вкладывают деньги, тратят их на сегодняшние нужды. Схемы поведения бедных традиционны, в основном люди могут рассчитывать на самих себя, но при этом надеются на чужую поддержку. Жизненные стратегии бедных обусловлены неблагоприятными жизненными условиями, не дающими возможность действовать иначе. Разница в исследовательских характеристиках в основном заключается в следующем: дискутируется зависимость стратегий от прошлого человека, способность человека в состоянии бедности на активизацию своей деятельности по преодолению этого состояния.

По нашему мнению, жизненные стратегии любого человека зависят от объективных условий его жизни (прошлого, настоящего, надежд на будущее) и свойств его личности, от особенностей мировоззрения. Людей в состоянии бедности окружают одинаковые по сути обстоятельства, разница в том, наследуемое это состояние или вновь приобретенное. Наследуемая бедность - отягчающее обстоятельство, т. к. она влияет на личностные (прежде всего мировоззренческие) особенности человека, прививает стереотипы поведения и т. п. Это лишает человека свободы выбора жизненных стратегий (который у бедных и так не велик).

С точки зрения развития любые неэффективные стратегии вредят обществу. Причина выбора индивидом неэффективных жизненных стратегий в том, что отношение этого человека и мира строится на зависимых мировоззренческих установках. Последние - peзультат рационального выбора индивида (за исключением наследственной бедности и депривации). Зависимые мировоззренческие установки присущи богатым и бедным. Богатые оберегают свое состояние, они зависят от него и способа приумножения этого состояния. Бедные зависят от внешних источников поддержки, от социального окружения, своих мировоззренческих установок, они тоже их оберегают, но своими способами (хотя бы тем, что не отказываются от своих зависимых стратегий). Однако как зависимые установки «сильных мира сего», так и такие же установки бедных не приводят к росту общественного благосостояния, хотя могут временно поправить положение на индивидуальном уровне, поэтому такие установки не являются эффективными. Только независимые жизненные установки приводят к эффективным стратегиям, тогда бедность может стать «катализатором человеческой деятельности», а богатство - инвестором общественного прогресса. 


\section{Заключение}

В исследовании были поставлены следующие задачи: учитывая переходное состояние современных обществ, выяснить, что изменяется в мировоззрении человека под влиянием бедности, какие возникшие в результате этого влияния свойства мировоззрения представляют наибольшее препятствие для развития человечества, что может быть изменено в общественном мировоззрении, в мировоззрении бедных для преодоления бедности и во имя развития. В результате проведенного исследования мы пришли к следующим выводам.

При изучении мировоззренческих особенностей необходимо учитывать тот факт, что в процессе исследования происходит столкновение мировоззрений исследователя и объекта исследования. Поэтому речь может идти только о создании модели-метафоры, которая сочетает интерпретационную разницу и объективную сторону исследования. При анализе социологических и других исследований было обнаружено существование подходов, в которых особенности мировоззрения бедных, их отношение к окружающему миру считается универсальным явлением в культуре. Универсальность свойственна «культуре бедности», для которой характерны зависимые установки в мировоззрении со всеми вытекающими из этого следствиями (иждивенчество, пассивность, агрессивность и т. п.). Также есть подходы, основанные на идее адаптации, - специфичность мировоззрения бедных обусловлена особыми адаптациями к состоянию бедности. Также считается, что исключение из общества бедных людей приводит к формированию андеркласса, противопоставленного остальному обществу, где присутствует регресс социализации человека, его когнитивных способностей и т. п. Также рассматривается зависимость специфики мировоззрения бедных от ситуации, при которой человек попадает в состояние бедности. С нашей точки зрения, существуют противоречия между социологическими, историческими фактами и подобными интерпретациями исследователей - это следствие противоречивости современного этапа развития общества, существования в нем мировоззрений с разными ценностными и когнитивными основаниями.

Выявлена специфичность влияния бедности на человека в условиях развития российского общества, последние становятся причиной формирования особенностей мировоззрения, свойственных российским бедным, и парадоксальности их самооценок. Причина парадокса видится в насаждении нашему обществу протестантских ценностей, противоречащих нашим традициям. Кроме этого, на самооценку бедных граждан РФ влияет тот факт, что наличие работы не спасает от бедности (бедность работающих людей). Следствием парадоксальности мировоззрения становится дезориентация людей в социальном пространстве, что приводит к потере статусной идентичности в самооценках, к несоответствию самооценок бедных объективному положению человека в обществе. Отмечается, что процесс «ухода в себя» бедных людей имеет разное проявление в России и на Западе. «Уход в себя» в сочетании с парадоксальностью мировоззрения российских бедных и с национальной особенностью российского общества как субъекта мировоззрения не приводит к потере связи с обществом, как, например, в Европе, где он позволяет сохранить себя, влиять на общество, самоидентифицироваться.

В аспекте изучения жизненных стратегий обнаружена наибольшая их зависимость от мировоззрения человека, чем от уровня обеспеченности. Существует влияние «зависимых установок» в мировоззрении на деятельность людей, отмечается отсутствие прямой связи наличия этих установок у личности с ее успешностью. Вскрыта зависимость стратегий от объективных условий, при которых человек попал в состояние бедности. Отношение людей в ситуации бедности к окружающему миру прежде всего зависит от того, депривированы они или нет. Депривированные бедные не берут на себя 
никаких обязательств. Однако положение зависимости рождает у них потребность в посторонней помощи, получение такой помощи затруднено в ситуации социального исключения. Поэтому депривированные бедные проявляют агрессию и негативное отношение к окружающему миру. Развивают альтернативные средства адаптации. Если бедный человек осознает себя деятельной частью общества, то это делает его наиболее социально активным, т. к. он лучше других понимает необходимость социальных изменений и что именно нужно менять в обществе.

Интерпретация бедными собственного положения зависит от социальноэкономических, политических условий общества, от культурных и мировоззренческих установок, господствующих в нем. Самоидентификация индивида зависит от психоэмоционального и физического состояния. Противоречия между самооценкой человека в состоянии бедности и окружающей его реальности могут привести к социальному взрыву. Кроме социального протеста существуют другие варианты избавления от нищеты. Это может быть «уход в себя», создание альтернативного мира или внутреннее приспособление и адаптация, которые даже могут создать иллюзию счастья. Бедные, оставленные один на один со своей нищетой, никогда не вырвутся из этого положения. Бедность не является стимулятором выработки новых продуктивных стратегий деятельности, т. к. наталкивается на множество не столько внешних, сколько внутренних преград. В сочетании с неблагоприятной социально-экономической и политической ситуацией бедность «консервируется», приобретая характер субъективной жизненной нормы. Жизненные стратегии бедного человека зависят от объективных условий его жизни и свойств его личности, от того, наследуемое у него состояние бедности или приобретенное. Наследуемая бедность отягощает положение человека, влияя на его личностные особенности, лишает человека свободы выбора жизненных стратегий (который у бедных и так не велик). Необходимо различать жизненные стратегии, приносящие временный результат в основном в индивидуальном плане, и эффективные жизненные стратегии. Неэффективные жизненные стратегии мировоззренчески основаны на зависимых установках, которые не связаны с уровнем благосостояния человека. Эффективной может считаться только та деятельность, которая способствует прогрессивному развитию общества, преодолению социальной несправедливости и неравенства, отрицает предыдущую логику развития и мировоззренчески основывается на независимых установках.

\section{СПИСОК ЛИТЕРАТУРЫ}

1. Зубкевич Л.А. Взаимосвязь социологических методик измерения бедности и развития человечества // Вестник Нижегородского университета им. Н.И. Лобачевского. Серия «Социальные науки». 2018. - № 4. - С. 90-98.

2. Зубкевич Л.А. Философия и исторические типы мировоззрения. - Нижний Новгород: НИУ РАНХиГС, 2016. - 100 с.

3. Агапов О.Д. Интерпретация как личностная форма творения бытия: дис. ... д-ра филос. наук. - Казань, 2011. - $453 \mathrm{c}$.

4. Агеева Е.Ю. Город как социокультурное образование. - Нижний Новгород: Изд-во ННГУ, 2004. 219 c.

5. Балабанова Е.С. Стратегии совладания с жизненными трудностями: самостоятельность или зависимость? // Экономическая социология. - 2002. - Т. 3. - С. 59-78.

6. Балабанова Е.С. Социально-экономическая зависимость как феномен сознания и стратегий поведения населения современной России: автореф. дис. ... д-ра социол. наук. - Нижний Новгород, 2006. $24 \mathrm{c}$.

7. Lewis Oskar. Culture of poverty // On understanding poverty: perspectives from the social sciences / Ed. by D.P. Moynihan. - Nev York: Basic Books, 1968. - 425 p.

8. Lewis Oscar. The culture of poverty // Scientific American. - 1966. - V. 215. - P. 19-25. 
9. Ишмуратова В.Г. Структурно-логическая причинно-следственная модель механизмов и инструментов борьбы с бедностью в условиях трансформационной экономики // Вестник Челябинского государственного университета. Экономика. - 2012. - № 10 (264). - Вып. 38. - С. 43-52.

10. Балабанова Е.С., Балабанов А.С. Процессы накапливания преимуществ и углубление депривации: к постановке исследовательской проблемы // Экономическая социология. - 2003. - Т. 4. - № 4. - С. $62-78$.

11. Сорокина А.В. Бедные в России: структура, ориентации, установки: автореф. дис. ... канд. социол. наук. - Нижний Новгород, 2003. - 18 с.

12. Пожилов И.В. Имущественные слои современной России: процесс становления социальнополитической рефлексии: автореф. дис. ... канд. социол. наук. - Нижний Новгород, 2004. - 16 с.

13. Фатенков А.Н. Философия подвижной иерархии (русский контекст). - Нижний Новгород: Изд-во ННГУ, 2005. - 322 с.

14. Карвацкий А., Антонович Д. Андеркласс и культура бедности в среде бывших государственных сельских хозяйств в контексте теоретических и интерпретационных дискуссий // Социология: теория, методы, маркетинг. - 2005. - № 1. - С. 36-70.

15. Poverty impedes cognitive function / Anandi Mani, Sendhil Mullainathan, Eldar Shafir, Jiaying Zhao // Sciense. - 2013. - V. 341. - № 6149. - P. 976-980. DOI: 10.1126/science.1238041

16. Бедность и неравенства в современной России: 10 лет спустя. Аналитический доклад. - М.: Институт социологии РАН, 2013. - 168 с.

17. Беляева Л.А. Социальная стратификация и бедность в регионах России (к составлению социокультурного портрета регионов) // Социологические исследования. - 2006. - № 9. - С. 52-63.

18. Ефремова М.В., Патоша О.И., Полуэктова О.В. Основные подходы к изучению феномена бедности в зарубежных психологических исследованиях // Современная зарубежная психология. - 2014. - Т. 3. № 3. - С. 91-101.

19. Худякова О.А. Владение техническим артефактом как феномен стратификации современного Российского общества: автореф. дис. ... канд. социол. наук. - Нижний Новгород, 2009. - 21 с.

20. Вотинцева Н.Н. Специфика ценностей и ценностного сознания в трансформирующемся обществе: автореф. дис. ... канд. философск. наук. - Пермь, 2008. - 19 с.

21. Дитон А. Великий побег: здоровье, богатство и истоки неравенства - М.: Изд-во Института Гайдара: Фонд «Либеральная Миссия», 2016. - 368 с.

22. Шаховская Л.С., Климакова К.О. Институционализация бедности в России: можно ли остановить этот процесс? // Национальные интересы: приоритеты и безопасность. - 2016. - № 3. - С. 67-78.

23. When the economy falters, do people spend orsave? Responses to resource scarcity depend on childhood environments / V. Griskevicius et al. // Psychological science - 2013. - № 24 (2). - P. 197-205. DOI: $10.1177 / 0956797612451471$

24. Черкасская Г.В. Борьба с бедностью как фактор развития института социальной защиты // Вестник Ленинградского государственного университета им. А.С. Пушкина. - 2010. - № 3. - Т. 6. - С. 77-86.

25. Duflo E. Human values and the design of the fight against poverty. Tanner Lectures. May 2012. URL: https://www.povertyactionlab.org/sites/default/files/documents/TannerLectures_EstherDuflo_draft.pdf (дата обращения: 12.08.2019).

26. Гаража Н.А. «Патернализм или свобода?». Концепты политики борьбы с бедностью Эстер Дюфло // Сибирский экономический вестник. - 2016. - № 3. - С. 5-17.

27. Представление о том, что бедность - следствие лени и отсутствия дисциплины - заблуждение. URL: https://news.un.org/ru/audio/2016/10/1036111 (дата обращения 29.05.2018).

Поступила 31.08.2019 2. 
UDC 101.1:316.344.2:148.8

\title{
IMPACT OF POVERTY AS A SOCIAL PHENOMENON ON THE WORLDVIEW OF PEOPLE IN MODERN CONDITIONS OF SOCIAL DEVELOPMENT (SOCIAL AND PHILIOSOPHICAL ANALISIS)
}

\author{
Lada A. Zubkevich, \\ lada-zubk@rambler.ru

\begin{abstract}
N.I. Lobachevsky National Research Nizhny Novgorod State University, 23, Gagarin avenue, Nizhny Novgorod, 603950, Russia.
\end{abstract}

Lada A. Zubkevich, Cand. Sc., senior lecturer, N.I. Lobachevsky National Research Nizhny Novgorod State University.

The relevance of the research is determined by the fact that the current stage of development of societies can be characterized as a transitional state, characterized by variability, multifactorial nature, inconsistency of all the processes, and especially ideological ones. At the same time, the main obstacle for development of both individual societies and humanity as a whole is poverty, which leads to other global problems. Therefore, the study of the characteristics of the modern people worldview in a state of poverty is relevant. The aim of this study is to determine the impact of poverty as a social phenomenon of societies in transition on the worldview of people. The categories of population of modern societies, which according to sociological assessments are poor, determine the area of study. Methods. Through a socio-philosophical analysis, it becomes clear how property of a world view represents the greatest obstacle in the conditions of the modern transitional state of society development. The worldview features of the poor are considered in the aspect of the subject's relation to the object; features of the interpretation of their own plight, characteristic of the poor strata of society. A socio-philosophical analysis of the life strategies of people in the situation of poverty is carried out. When implementing socio-philosophical reflection the author relies on the data of sociological research, taking their assessment as proven. The author applies as well the method of comparative analysis of the author's position of sociologists; «Polydiscursive» methodology and methodological «principle of participatory thinking». Results. It was found that deprivation is the most dangerous subject-object relation; it develops alternative means of adaptation to reality. The poor, without the help of society, cannot break out of poverty, since it is not a stimulator of the development of new productive strategies for action.

Key words: Deprivation, underclass, culture of poverty, effective life strategies, well-being, social inequality, socio-economic dependence, dependent attitudes.

\section{REFERENCES}

1. Zubkevich L.A. Interrelation of sociological methods for measuring poverty and human development. Bulletin of Nizhny Novgorod University. N.I. Lobachevsky. Series: Social Sciences, 2018, no. 4, pp. 90-98. In Rus.

2. Zubkevich L.A. Filosofiya $i$ istoricheskie tipy mirovozzreniya [Philosophy and historical types of worldview]. Nizhniy Novgorod, NRU RANEPA Publ., 2016. 100 p.

3. Agapov O.D. Interpretatsiya kak lichnostnaya forma tvoreniya bytiya. Dis. Dokt. nauk [Interpretation as a personal form of the creation of being. Dr. Diss.]. Kazan, 2011. 453 p.

4. Ageeva E.Yu. Gorod kak sociokulturnoe obrazovanie: monografiya [City as a sociocultural education: monograph]. Nizhniy Novgorod, NNGU Publ., 2004. 219 p.

5. Balabanova E.S. Strategies for coping with life difficulties: independence or dependence? Economic sociology, 2002, vol. 3, pp. 59-78. In Rus. 
6. Balabanova E.S. Sotsialno-ekonomicheskaya zavisimost kak fenomen soznaniya i strategiy povedeniya naseleniya sovremennoy Rossii. Avtoref. Dis. Dokt. nauk [Socio-economic dependence as a phenomenon of consciousness and behavioral strategies of the population of modern Russia. Dr. Diss. Abstract]. Nizhniy Novgorod, 2006. 24 p.

7. Lewis Oskar. Culture of Poverty. On understamding poverty: perspectives from the social sciences. Ed. by D.P. Moynihan. Nev York, Basic Books, 1968. 425 p.

8. Lewis Oscar. The culture of poverty. Scientific American Issue Number, 1966, vol. 215, pp. 19-25.

9. Ishmuratova V.G. Structural and logical causal model of mechanisms and tools to combat poverty in a transformative economy. Bulletin of Chelyabinsk State University, 2012, vol. 38, no. 10 (264), pp. 43-52. In Rus.

10. Balabanova E.S., Balabanov A.S. The processes of accumulation of benefits and the deepening of deprivation: to the formulation of a research problem. Economic sociology, 2003, vol. 4, no. 4, pp. 62-78. In Rus.

11. Sorokina A.V. Bednye v Rossii: struktura, orientatsii, ustanovki. Avtoref. Dis. Kand. nauk [The poor in Russia: structure, orientation, installation. Cand. Diss. Abstract]. Nizhniy Novgorod, 2003. 18 p.

12. Pozhilov I.V. Imushchestvennye sloi sovremennoy Rossii: protsess stanovleniya sotsialno-politicheskoy refleksii. Avtoref. Kand. nauk [Property layers of modern Russia: the process of formation of socio-political reflection. Cand. Diss. Abstract]. Nizhniy Novgorod, 2004. 16 p.

13. Fatenkov A.N. Filosofiya podvizhnoy ierarkhii (russkiy kontekst) [The philosophy of the moving hierarchy (Russian context)]. Nizhniy Novgorod, NNGU Publ., 2005. 322 p.

14. Karvatsky A., Antonovich D. Andnrklass and the culture of poverty among the former state-owned agriculture in the context of theoretical and interpretative discussions. Karvatsky Arkadiusz, Antonovich Dominic; per. from Polish N. Sidyachenko. Sociology: Theory, Methods, Marketing, 2005, no. 1, pp. 36-70. In Rus.

15. Mani A. Poverty impedes cognitive function. Sciense, vol. 341, no. 6149, pp. 976-980.

16. Bednost i neravenstvo v sovremennoy Rossii: 10 let spustya [Poverty and inequality in modern Russia: 10 years later]. Analiticheskiy doklad. [Analytical report. Prepared in cooperation with the Representation of the Friedrich Ebert Foundation in the Russian Federation.]. Moscow, Institute of Sociology Publ. house, Russian Academy of Sciences, 2013. 168 p.

17. Belyaeva L.A. Social stratification and poverty in the regions of Russia (to compile a socio-cultural portrait of the regions). Sociological Studies, 2006, no. 9, pp. 52-63. In Rus.

18. Efremova M.V., Patosha O.I., Poluektova O.V. The main approaches to the study of the phenomenon of poverty in foreign psychological research. Modern foreign psychology, 2014, vol. 3, no. 3, pp. 91-101. In Rus.

19. Khudyakova O.A. Vladenie tekhnicheskim artefaktom kak fenomen stratifikatsii sovremennogo Rossiyskogo obshchestva. Avtoref. Dis. Kand. nauk [Possession of a technical artifact as a phenomenon of stratification of the modern Russian society. Cand. Diss. Abstract]. Nizhniy Novgorod, 2009. 21 p.

20. Votintseva N.N. Spetsifika tsennostey i tsennostnogo soznaniya v transformiruyushchemsya obshchestve. Avtoref. Dis. Kand. nauk [The specificity of values and value consciousness in a transforming society. Cand. Diss. Abstract]. Perm, 2008. 19 p.

21. Diton A. Velikiy pobeg: zdorovye, bogatstvo i istoki neravenstva [The Great Escape: health, wealth and the sources of inequality]. Moscow, Institute of Gaidar Publ. house; Foundation «Liberal Mission» Publ., 2016. $368 \mathrm{p}$.

22. Shakhovskaya L.S., Klimkova K.O. The institutionalization of poverty in Russia: is it possible to stop this process? National interests: priorities and security, 2016, no. 3, pp. 67-78.

23. Griskevicius V. When the economy falters, do people spend orsave? Responses to resource scarcity depend on childhood environments. Psychological sciense, 2013, no. 24 (2), pp. 197-205.

24. Cherkasy G.V. The fight against poverty as a factor in the development of the institute of social protection. Bulletin of the Leningrad State University A.S. Pushkin, 2010, no. 3, vol. 6, pp. 77-86.

25. Duflo E. Human values and fight against poverty. Tanner Lectures, May 2012. Available at: http://economics.mit.edu/files/7904 (accessed 29 July 2018).

26. Garazha N.A. «Paternalism or Freedom?». Esther Duflot's anti-poverty policy concepts. Siberian Economic Journal, 2016, no. 3, pp. 5-17. In Rus.

27. Predstavlenie o tom, chto bednost - sledstvie leni i otsutstviya discipliny - zabluzhdenie [The notion that poverty is the result of laziness and lack of discipline is a mistake]. Available at: https://news.un.org/ru/audio/2016/10/1036111 (accessed 29 May 2018).

Received: 31 August 2019. 